\title{
Income Inequality and the Persistence of Racial Economic Disparities
}

\author{
Robert Manduca
}

Harvard University

\begin{abstract}
More than 50 years after the Civil Rights Act, black-white family income disparities in the United States remain almost exactly the same as what they were in 1968. This article argues that a key and underappreciated driver of the racial income gap has been the national trend of rising income inequality. From 1968 to 2016, black-white disparities in family income rank narrowed by almost one-third. But this relative gain was negated by changes to the national income distribution that resulted in rapid income growth for the richest-and most disproportionately white-few percentiles of the country combined with income stagnation for the poor and middle class. But for the rise in income inequality, the median black-white family income gap would have decreased by about 30 percent. Conversely, without the partial closing of the rank gap, growing inequality alone would have increased the racial income gap by 30 percent.
\end{abstract}

Keywords: income inequality; race; stratification; disparities

Citation: Manduca, Robert. 2018. "Income Inequality and the Persistence of Racial Economic Disparities." Sociological Science 5: 182-205.

Received: December 11, 2017

Accepted: January 6, 2018

Published: March 12, 2018

Editor(s): Jesper Sørensen, Sarah Soule

DOI: $10.15195 /$ v5.a8

Copyright: (C) 2018 The Author(s). This open-access article has been published under a Creative Commons Attribution License, which allows unrestricted use, distribution and reproduction, in any form, as long as the original author and source have been credited. (0)(1)
THE stubborn persistence of racial income disparities has been a core frustration of American social policy for the past 50 years (Bloome 2014; Bound and Freeman 1992; Wilson and Rodgers 2016). In 1968, shortly after the passage of the Civil Rights Act, the median family income of African Americans was 57 percent that of whites. In 2016, after almost 50 years of anti-discrimination legislation, attempts to equalize access to education, and cultural change, it was 56 percent.

The persistence of the racial income gap is puzzling in light of efforts to equalize employment opportunity and progress toward racial equality in other areas. Following the civil rights movement, the federal government created agencies charged with reducing racial disparities across a variety of contexts (Pedriana and Stryker 2017). Companies across the country created well-staffed offices dedicated to countering discrimination in the workplace (Dobbin and Sutton 1998) and were often sued when they fell short (James and Wooten 2006). Racial gaps in educational attainment and cognitive test scores declined (Jencks and Phillips 2011; Neal 2006; Ryan and Bauman 2016), as did disparities in non-economic outcome measures, such as life expectancy (Kochanek, Arias, and Anderson 2013). During this period, white racial attitudes toward blacks improved across many domains: acceptance of integration and intermarriage increased and beliefs in the categorical inferiority of blacks and the legitimacy of racial discrimination declined (Bobo et al. 2012).

A massive academic and policy literature has sought to determine what drives the racial income gap and why it has remained so intransigent over the past 50 years. Sophisticated audit studies have shown that racial discrimination remains a key force at all levels of the labor market (Gaddis 2015; Pager 2003). Regressionbased decomposition analyses suggest that observable characteristics, such as work 
experience and educational background, play some role, although the magnitude of their contribution is debated (Blinder 1973; Neal and Johnson 1996; Wilson and Rodgers 2016). Some portion of the gap is explained by occupational segregation, itself influenced by discrimination and pre-market factors (Hamilton, Austin, and Darity 2011; Tomaskovic-Devey 1993).

This article argues that one underappreciated driver of the racial income gap has been the shape of the income distribution itself. Over the past 40 years, there has been a dramatic increase in the share of economic resources going to the very wealthy combined with income stagnation for everyone else. This shift has disproportionately harmed African Americans, who remain overrepresented in the less affluent portions of the income distribution (Bayer and Charles 2016; Juhn, Murphy, and Pierce 1991; Wilson and Rodgers 2016).

Here, I quantify the effect of changes in the income distribution on black-white family income disparities by decomposing overall trends into changes in rank and changes in the income earned at each rank. I show that the steady ratio between median black and median white family incomes conceals two large and diametrically opposed trends. From 1968 to 2016, African Americans made real albeit incomplete progress up the income distribution; racial disparities in income rank narrowed by about 30 percent. But that moderate progress in rank terms was negated by changes to the national income distribution that reduced earnings among the poor and middle class compared to the very rich. Because African Americans remained disproportionately concentrated in those lower portions of the distribution, they bore the brunt of economic changes that have hurt low-income workers of all races. These two forces almost perfectly balanced each other such that the overall ratio of median (or mean) black to white family income remained roughly constant.

These findings provide cause for both optimism and pessimism. On the one hand, they suggest that African Americans were more successful in advancing economically than previously believed. Blacks did make real strides up the income distribution despite continued disparities in parental wealth (Nam et al. 2015; Oliver and Shapiro 1995), access to high-quality education (Darling-Hammond 1998; Kozol 1991; Orfield and Lee 2005), family structure (Bloome 2014), and treatment in the labor market (Gaddis 2015; Pager 2003). But just as they were working their way up the income distribution, the distribution itself was collapsing down around them. This meant that they were denied the economic rewards that previous groups of Americans received upon mass entry into the middle class. Their upward relative mobility has amounted to a rearguard action that merely prevented the exacerbation of an already large racial income gap. Moving forward, today's high levels of income inequality further encumber the difficult struggle for racial economic equality. Because the income distribution has become so unequal, each hard-won increase in relative status (outside the very top) now translates into a smaller absolute rise in income.

These results reemphasize the importance of jointly studying economic inequality and racial stratification. These two topics stand at the core of sociology, yet they are often studied in isolation. Scholars of racial stratification have focused their attention on disparities and gaps (Leicht 2008; Morris and Western 1999), neglect- 
ing the impact of larger shifts in the economy and the income distribution-what William Julius Wilson has called "indirect structural forces" (Smelser, Wilson, and Mitchell 2001; Wilson 2009). As I document, a major cause of racial disparities is cross-racial income stagnation. The results presented here underscore the insight held by generations of civil rights activists: racial inequality and economic inequality are fundamentally intertwined (A. Philip Randolph Institute 1966; Jackson 1984; King 1968). Indeed, they are arithmetically inseparable.

\section{Previous Research}

\section{Racial Income and Earnings Disparities}

Numerous studies over the past two decades have documented that income and earnings gaps between African Americans and whites have either persisted (Blank 2001; Bloome 2014; Bradbury 2002; Smith 1993) or increased (Bayer and Charles 2016; Bound and Freeman 1992; Cancio, Evans, and Maume, Jr. 1996; Wilson and Rodgers 2016) since the 1960s, depending on the exact income measure used. During this period, there was a substantial though incomplete narrowing of the gaps in college attendance rates (Ryan and Bauman 2016), test scores (Jencks and Phillips 2011), and life expectancy (Kochanek et al. 2013). There were also considerable efforts on the part of the government and many corporations to promote racial equality (Dobbin and Sutton 1998; Pedriana and Stryker 2017). Given these more promising trends in other areas, much research on racial inequality has attempted to identify the mechanisms behind persistent income disparities.

Studies looking at individual labor market outcomes have proposed a variety of explanations for the persistent earnings gap. A common tactic is to decompose the overall disparity in earnings into differences in observable characteristics, such as education level or work experience, and differences in the returns to those characteristics (Blinder 1973; Oaxaca 1973). For instance, if the returns to education are different for blacks than for whites, that is considered evidence of discrimination (Darity 1998). Studies in this vein have found that observed differences in "premarket" characteristics, such as years of schooling, standardized test scores, and "soft skills" (which are, of course, to a large extent socially determined), explain some of the gap in wages (Moss and Tilly 1996; Neal and Johnson 1996), but that discrimination remains a major contributor to the earnings gap (Wilson and Rodgers 2016).

A second approach to understanding labor market disparities has been to explicitly test for discrimination. Studies in this vein conduct audit studies by responding to real job advertisements. They have consistently documented that black applicants are substantially less likely than whites with identical qualifications to be offered interviews or callbacks across a wide variety of settings (Bendick, Jackson, and Reinoso 1994; Bertrand and Mullainathan 2004), including both low-wage (Pager 2003; Pager, Bonikowski, and Western 2009) and high-qualification (Gaddis 2015) labor markets.

A third perspective looks at occupational segregation by race. These studies have shown that for the most part, blacks and whites hold very different jobs, and 
the jobs held by whites tend to be better (Hamilton et al. 2011; Tomaskovic-Devey 1993). This means that some of the racial income gap is due to differences in who gets which jobs. There is evidence that occupational segregation is decreasing and that blacks are entering high-status occupations at greater rates than in the past (Farley 1998; King 1992). Even within jobs, however, blacks tend to earn less than observationally similar whites. This pattern is more pronounced in higher-status occupations (Grodsky and Pager 2001; Huffman 2004).

A smaller number of studies have examined racial disparities in family income, which are the focus of this article. Family income captures the economic status of individuals more fully than do labor market outcomes on their own (Harding et al. 2005). It is affected by labor market outcomes but also by family structure-how many members families have and how many of them work (Martin 2006; Western, Bloome, and Percheski 2008). Racial disparities in family income have remained roughly constant since the 1960s (Blank 2001; Bloome 2014; Isaacs 2007). Differences in typical family structure between African Americans and whites-most notably, the higher prevalence of single-parent families among African Americans-are believed to be a major reason for the lack of improvement (Bloome 2014; Isaacs 2007). Here, I argue that another important reason for the lack of progress is rising income inequality at the national level.

\section{Extent and Sources of Rising Income Inequality}

Racial progress, or the lack thereof, is not the only major social change in the United States of the past 50 years. Perhaps the most widely felt change has been the systematic tilting of the U.S. economy toward the rich. Real pretax incomes for the richest 1 percent of society have risen by a factor of 3 since 1970 while incomes for the poorer half of society have hardly budged (Piketty, Saez, and Zucman 2016).

Importantly, income inequality appears to have risen within most major subgroups of society simultaneously. Inequality has gone up for blacks and whites (Bayer and Charles 2016), men and women, high school and college graduates, and people across many age ranges (Lemieux 2006). It has also grown within occupations (Kim and Sakamoto 2008) and within family types (Martin 2006; Western et al. 2008). Though the changes vary in size for different social groups, this broad footprint suggests that the growth of income inequality is truly one nationwide trend and not a series of separate stratification processes. The concentration of income is a major departure from trends during the prosperous middle of the twentieth century. Growth during that time was broad based, with family incomes for all quintiles growing by more than 2 percent per year from 1947 to 1973. Since 1973, only the highest quintile has seen growth of more than 1 percent per year, and the poorest quintile has seen incomes decline (Wilson 2000).

The takeoff in income inequality was well documented by the early 1990s (Harrison, Tilly, and Bluestone 1986; Levy and Murnane 1992). There has been considerable debate as to its sources. Perhaps the most prominent explanation has been skill-biased technological change. As typically formulated, this theory argues that changes in technology over the past 40 years have increased the demand for college-educated workers, raising their value in the labor market and thus their 
earnings relative to workers with a high school degree (Autor 2014; Autor, Levy, and Murnane 2003; Goldin and Katz 2010).

Skill-biased technological change has been extremely influential in informing policy and scholarship, but the hypothesis faces several challenging facts. Throughout the time when demand for college-educated workers is hypothesized to have been increasing, there has been a consistent oversupply of college graduates relative to the number of jobs requiring a college degree (Abel, Deitz, and Su 2014; Hecker 1992). Further, the observed changes to the income distribution do not fit those predicted by skill-biased technological change, which emphasizes the increasing gap between college-educated and high school-educated workers. Income growth was concentrated among the richest 1 percent, which is a much more select group than that of all college graduates (Piketty et al. 2016). Moreover, most of the rising college premium was created by a decrease in the real wages of high school-educated workers rather than an increase in the real wages of college graduates (Gottschalk 1997).

Alternative explanations for the increase in income inequality have emphasized institutional changes to the labor market and the economy at large that have reduced the bargaining power of the less affluent and increased the bargaining power of the very rich (Jacobs and Dirlam 2016; Levy and Temin 2007; Volscho and Kelly 2012). These include the decline of the labor movement (Western and Rosenfeld 2011), lower minimum wages (DiNardo, Fortin, and Lemieux 1996; Lee 1999), decreasing enforcement of antitrust laws (Comanor and Smiley 1975; Khan and Vaheesan 2016), the lowering of trade barriers (Alderson and Nielsen 2002; Autor, Dorn, and Hanson 2016), and reductions in top income tax rates (Piketty, Saez, and Stantcheva 2014). Each of these policies was a departure from the institutional framework of the mid-twentieth century, and many were actively pursued by organized interest groups starting in the 1970s, which is exactly when income inequality began to rise (Hacker and Pierson 2010).

Understanding the causes of rising income inequality is important because to the extent that the income distribution is shaped by political action, the income that accrues to any particular person is a function of political choices made by society as well as a function of one's own background and skills. If that is true, it makes conceptual sense to separate the labor market position of an individual-here operationalized as his or her rank in the income distribution-from the specific monetary income he or she earns and to analyze trends in each independently. That is the approach I take in this article.

\section{The Relationship between Economic Structure and Racial Disparities}

The potential interactions between overall economic structure and racial disparities have not gone unnoticed within sociology or economics. The interaction between macroeconomic shifts, segregation, and racial disparities forms a core pillar of the scholarship of William Julius Wilson $(1978,1987,1996,2009)$. Throughout his work, Wilson has emphasized the importance of "indirect structural forces," such as changes in the types of jobs available or the spatial locations of those jobs, 
in shaping racial disparities (Smelser et al. 2001). Although these forces appear orthogonal to questions of racial inequality and do not necessarily have their origins in any racialized process, they have disproportionately harmed African Americans and other groups that are concentrated among the less affluent parts of society. Economists have also noted that changes to the overall economy may have different effects on different racial groups. African Americans are particularly affected by the business cycle, with boom periods-most notably the full-employment economy of the late 1990s - being especially good for black incomes and bust periods being especially bad (Freeman and Rodgers 1999; Wilson 2015).

The most direct predecessors to this article are studies that have found the national rise in income inequality to be a major contributor to the black-white earnings gap. Bayer and Charles (2016) applied methods that are similar to those used here to Decennial Census data to show that the median black-white earnings gap among working-age men has increased since 1980 and that the median rank gap has stayed constant since 1940, although rank disparities at higher income percentiles have narrowed. Like this article, they concluded that overall macroeconomic trends have had a major influence on racial income disparities.

A more common method, developed by Juhn et al. (1991), is to first perform a Oaxaca-Blinder decomposition of the overall change in disparities into changes in observable characteristics and changes in the returns to those characteristics. The residuals are further decomposed into changes in the position of blacks within the white residual distribution and changes in the spread of that distribution. The proportion of the total change falling into the last category-changes in the spread of the residuals for whites-is interpreted as the portion of the change due to rising inequality. Juhn et al. found that rising inequality explained almost all of the lack of racial convergence in the 1980s. Couch and Daly (2002) suggested that continued dispersion kept convergence in the 1990s smaller than it would have been otherwise. Bringing the analysis forward to the present day, Wilson and Rodgers (2016) found that rising income inequality and continued discrimination are the two primary reasons for the continued lack of earnings convergence. In an exercise that anticipated the counterfactual portion of this study, Smith (1993) employed a statistical adjustment to control for the rise in inequality during the 1980s and estimated that without that rise the racial wage gap would have continued to decline through that decade.

The studies referenced here provide evidence for Wilson's claim that indirect structural forces are extremely influential in determining the relative fortunes of blacks and whites. Because African Americans remain-despite improvements, as I will show below-disproportionately concentrated in the lower portions of the income distribution, structural changes that harm all low-income people will also increase the gap between blacks and whites. This is a specific instance of a general principle that follows from Peter Blau's macrosociological theory of social structure (Blau 1974, 1977a, 1977b). Blau noted that individuals can be differentiated into nominal groups, such as race, and via graduated parameters, such as income. If nominal and graduated parameters are correlated, a change that occurs solely along the graduated parameter, such the pulling away of the top of the income distribution, will alter the relative positions of the nominal groups. Put another way, 


\section{Stylized illustration of inequality and group disparities}

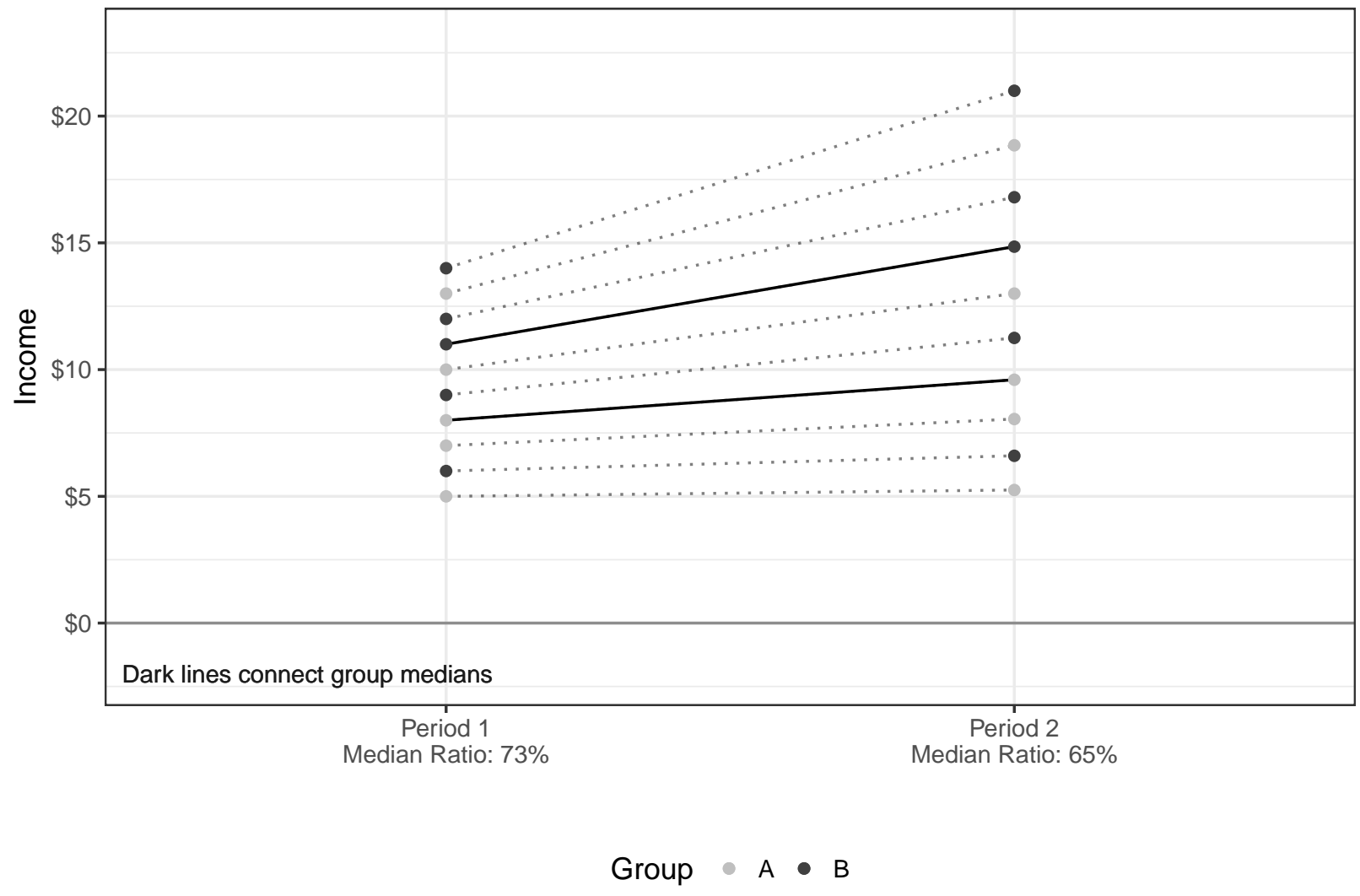

Figure 1: Rising income inequality can exacerbate cross-group disparities. As inequality rises from Period 1 to Period 2, the gap between the groups grows even though no further group-based stratification has occurred.

once racial inequality exists, increases in economic inequality will exacerbate racial disparities even if they are not rooted in explicitly racialized processes. Economic inequality and racial inequality are arithmetically inseparable.

To illustrate this phenomenon, consider Figure 1. It shows a hypothetical society at two points in time. The society has 10 members, who are equally divided into two nominal groups. Members of each group are found throughout the income distribution, but members of Group A are more heavily concentrated toward the bottom, whereas members of Group B are weighted toward the top. The median Period 1 income of Group A is $\$ 8$, and that of Group B is $\$ 11$.

In Period 2, there has been a societywide increase in inequality. Incomes have grown for everyone but by an amount that is proportional to rank. The income of the poorest person grew by 5 percent, whereas that of the richest grew by 50 percent. Note that the shift is rank preserving: everyone occupies the same position in the income distribution that they did before. Nevertheless, the income disparity between groups has increased, with the ratio of group medians falling from 73 percent to 65 percent. The ratio of group means falls from 83 percent to 78 percent. Because group membership and income are correlated-even though 
that correlation is not perfect-shifts in the income distribution alone are enough to change the relative status of groups. No explicitly group-based process is required.

\section{Data and Methods}

This article studies black-white family income disparities for the years 1968 to 2016. Following a common practice in studies of stratification, I separately analyze the allocation of positions-here, ranks in the income distribution-and the assignment of rewards to those positions (Weeden 2002). This allows me to isolate changes in the income gap that are due to changes in the income ranks of blacks and whites from those that are due to changes in the shape of the income distribution.

I use microdata from the 1968-2016 Current Population Survey (CPS) March Supplement obtained from the Integrated Public Use Microdata Series (IPUMS) project (Flood et al. 2015). In my baseline specification, I analyze the annual pretax family incomes of all individuals. Families are defined as related individuals living together. This is distinct from households, which include all individuals living together even if they are unrelated. I also run specifications limiting to adults only and using household rather than family income. I do not normalize income by family size in the baseline, measuring the total economic resources that are available to each family. However, the results are robust to normalizing by the square root of family size, which is a common practice (Johnson, Smeeding, and Torrey 2005), and to normalizing by the total number of family members, which is extremely conservative.

In my baseline analysis, I identify as black all individuals who self-describe their race as black or African American only and do not identify their ethnicity as Hispanic. ${ }^{1}$ Similarly, whites are defined as people who identify their race as white only and do not identify as Hispanic. In a supplementary analysis, I identify as black all individuals who report any African ancestry, including those who identify as mixed race and those who identify as Hispanic. I also perform a supplementary analysis limiting the sample to those born in the United States to two U.S.-born parents.

I calculate income ranks by computing income percentiles for the entire national population, not just blacks and whites, although my results are robust to limiting the sample to blacks and whites only. Observations are weighted using the CPS survey weights. In cases in which a single income amount, such as $\$ 0$, is held by more than 1 percent of people, I compute the median percentile falling in that range and assign it to all the individuals with that income. I exclude people reporting negative incomes from the analysis. All data used in this analysis are publicly available on the IPUMS website, and all the code used to conduct the analysis is publicly available on the author's website.

An advantage of the CPS is that income data are collected yearly, so it is possible to study trends in great temporal detail. However, the sample has a few major limitations. First, the CPS does not include individuals who are institutionalizedincarcerated, in mental institutions, or in homes for the elderly. Because a substantial proportion of black men in particular are in prison at any given moment and because the men likely to be incarcerated are also likely to have limited labor market success, 
the absence of the incarcerated population artificially reduces the estimated racial disparities (Western and Pettit 2005). This omission is problematic, although because my analysis considers family income for all individuals the bias should be smaller than it would be in a study of adult men. Further, the bias should affect ranks as well as income levels and thus not contribute greatly to the difference between the two measures, which is my primary interest. In an attempt to account for this possible bias, I conduct a supplementary analysis in which I calculate the institutionalization rate by race in the Decennial Census and add that population back into the CPS sample, assuming that all the people who are institutionalized earn less than the median for their race. This does not change the qualitative findings.

A second limitation of the sample arises because the CPS, like other surveys, has trouble gathering data on the lowest- and highest-income members of society (Bollinger et al. 2014). To the extent that the CPS misses rich individuals, who are disproportionately white, my estimates will understate the amount and thus the impact of income inequality. To the extent that it misses poor individuals, who are disproportionately black, it will overstate the amount of racial progress. Again, though, it should overstate progress in both rank and income terms, meaning that the discrepancy between the two should be affected less than either statistic on its own. Further, because I use median rather than mean incomes, the influence of outlying values is limited. This means that the top-coding of extremely high values does not bias the statistics I use. It also means that the effect of missing extremely high or low values is the same as that of missing any other observation above or below the median respectively.

\section{Findings}

\section{The Remarkable Stability of the Racial Income Gap}

I first replicate the previous finding that the racial income gap has remained remarkably stable over the past 50 years (Bloome 2014). Figure 2 plots the ratio of black to white mean and median annual family and household income. The four lines are almost identical and perfectly flat: The median ratio for family income was 57 percent in 1968 and 56 percent in 2016. For household income, the median ratio dropped from 60 percent to 59 percent during this period. Mean ratios were similarly unchanging, and no statistic ever fluctuated more than a few percentage points from its average value. There has been very little change in the economic status gap between blacks and whites over the last 50 years.

\section{Rank Progress and Distributional Backsliding}

The overall lack of change shown in Figure 2 is the product of two pronounced but diametrically opposed trends. African Americans have made progress in relative terms, occupying higher average ranks in the income distribution than they did in the 1960s (though the gap between whites and blacks remains quite large). But this progress has been counteracted by shifts in the overall income distribution 


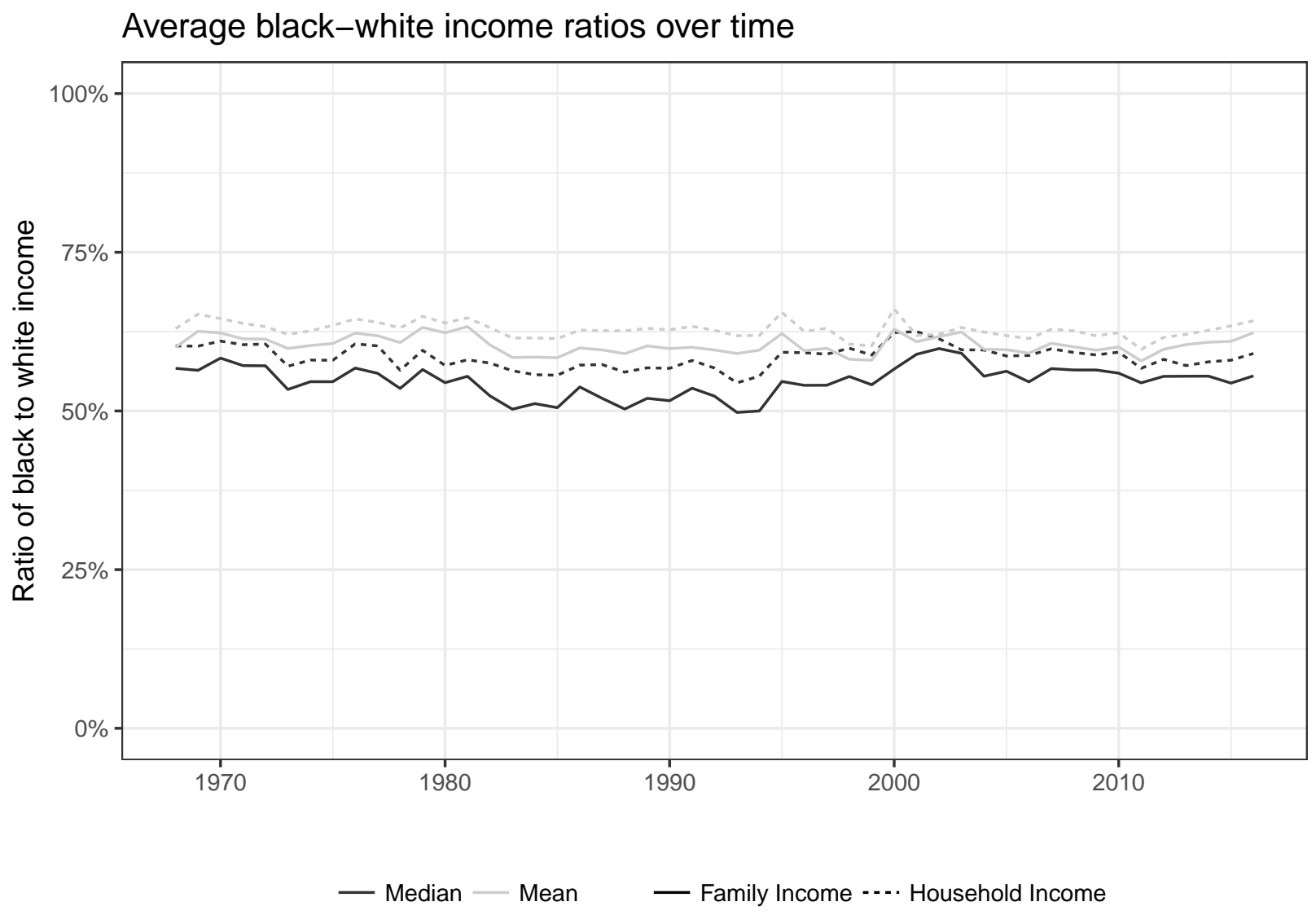

Figure 2: Median and mean black-white income ratios over time.

that have disproportionately harmed the poor and middle class and thus African Americans.

These conflicting trends are illustrated in Figure 3. Focusing on total family income, Figure $3 \mathrm{~A}$ first plots the overall black-white median income ratio from Figure 2. It is remarkably constant over the almost 50 years covered by these data. However, Figure 3B plots the median income rank of blacks over this time. Here, there is a marked increase: the median African American had a family income at the 25th percentile of the national distribution in 1968 but had climbed to the 35th percentile in 2016. In contrast, the median white family hardly shifted, going from the 54th percentile in 1968 to the 57th percentile in 2016 (not shown). As a result, the rank gap in family income between blacks and whites fell by 28 percent. This is not an overwhelming success, to be sure, but it is meaningful progress.

Unfortunately, this moderate progress in relative terms was counteracted by changes to the income distribution that disproportionately harmed the less affluent. Figure $3 \mathrm{C}$ plots the ratio of family income at the 35 th percentile of the national income distribution - the median rank of blacks in 2016-to the national mean family income from 1968 to 2016. It shows a dramatic decline. In 1968, an income at the 35 th percentile meant a standard of living that was roughly 69 percent of 

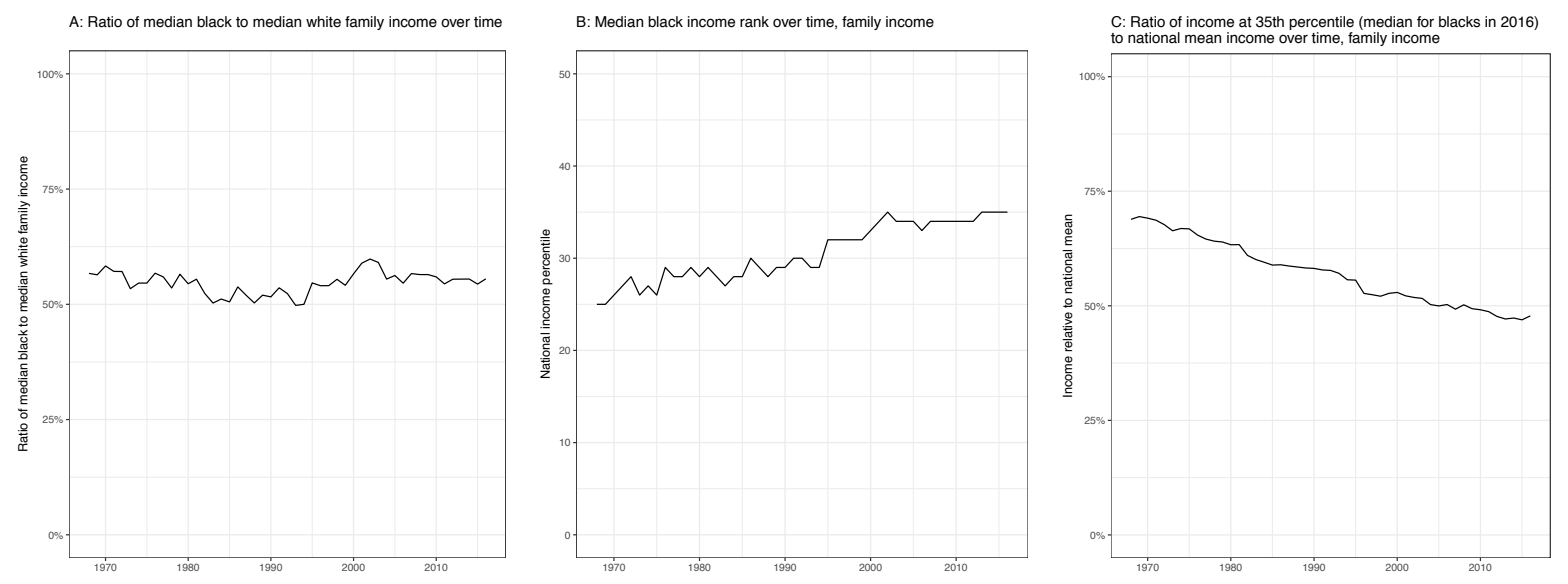

Figure 3: Median black-white family income ratio, median black rank, and income at the 35th percentile as a percentage of the national mean over time.

the national average. In 2016, it meant one just 48 percent as large. Income at the 35th percentile fell by 31 percent relative to the country overall from 1968 to 2016, meaning that the reward that the median black family received for being at that position in 2016 was almost one-third lower than it would have been when the civil rights reforms were enacted. Perhaps most incredibly, family income at the 25th percentile in 1968 was 55 percent of the national mean in that year, meaning that despite being almost 50 percent higher in the national income distribution, the median black family earned a smaller percentage of the national mean income in 2016 than in 1968.

Importantly, income for the median white family also fell relative to the national mean during this time, but not by as much. Income at the 57 th percentile-the median rank for whites in 2016-was about 99 percent of the national mean income in 1968. By 2016, it had fallen to 85 percent, which is a decline of 14 percent.

The qualitative result that the stagnant black-white median income ratio results from rank progress negated by distributional backsliding is robust to a wide range of income definitions and sample constructions. Alternate income definitions that I consider include household income, family income normalized by the square root of family size, and family income normalized by family size. Alternate sample constructions include limiting the sample to adults only to account for differences in fertility by race or class, limiting the sample to blacks and whites only, using an expanded definition of black that incorporates anyone claiming any African ancestry (including those who also identify as Latino or any other race), limiting the sample to only native-born U.S. citizens with two U.S.-born parents (in case immigrant blacks have higher incomes than native-born ones), ${ }^{2}$ and adjusting for the institutionalized population. ${ }^{3}$ These robustness checks are shown in Figure 4. In all cases, there was a marked increase in the median rank of African Americans 

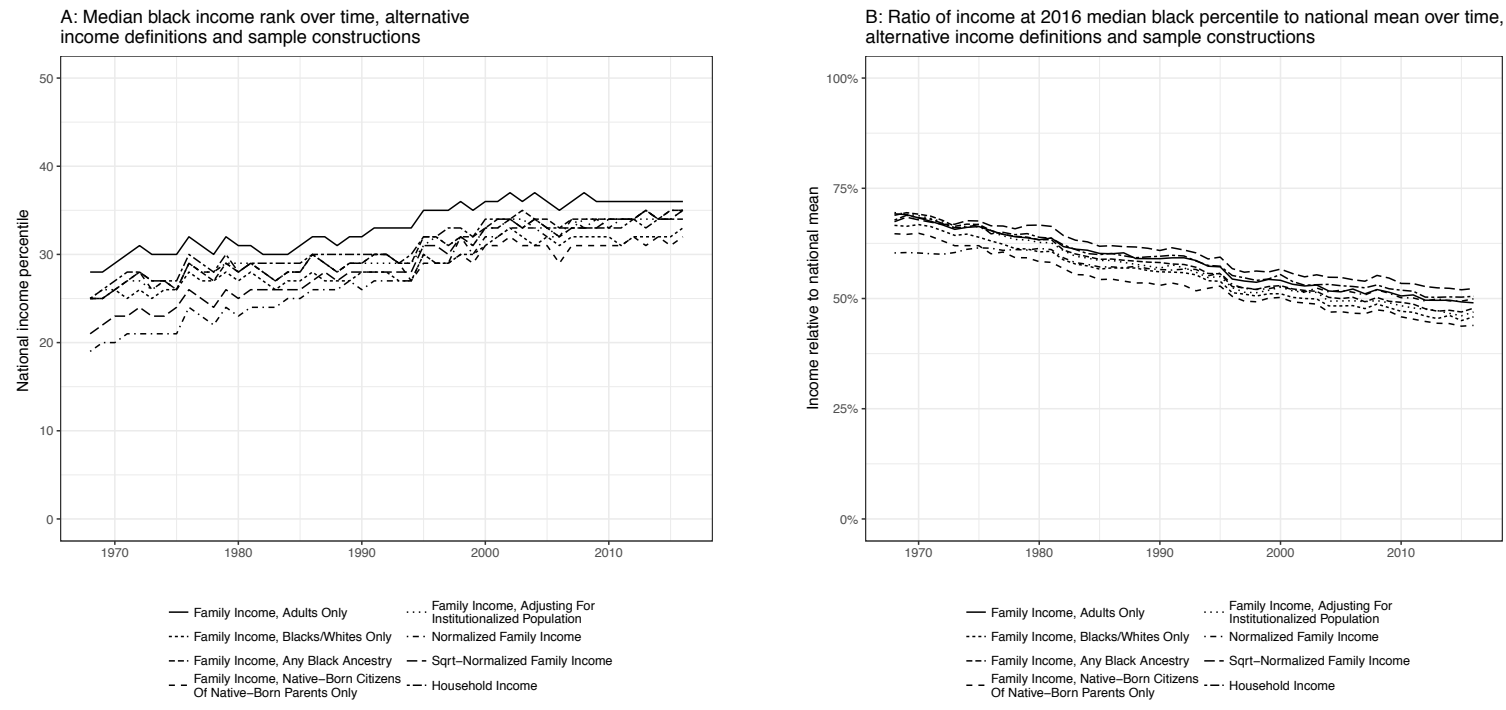

Figure 4: Alternative income definitions and sample constructions.

in the national income distribution but a decline in the income associated with their final rank relative to the national mean.

\section{Trends across the Income Distribution}

Broadening the scope from the median to the entire income distribution, Figure 5A shows changes in national family income rank at each decile of the black income distribution. Progress in rank terms was steepest in the middle of the distribution, with smaller progress at the very top and hardly any change for the 10th and 20th percentiles.

Figure 5B shows the incomes associated with the final ranks as a percentage of national mean income over time. For instance, the 90th percentile of the black income distribution was at the 81st percentile of the national income distribution in 2016. So the top line in Figure 5B shows income at the 81st percentile relative to the national mean over time. Figure 5B makes clear how much the changing income distribution has harmed African Americans. Only the richest 10 percent of African Americans ended up in the small portion of the distribution in which incomes rose relative to the national mean over the past 50 years. The poorest 70 percent were in portions of the distribution in which income shares contracted substantially. Because whites are richer than average (in 2016, 12.0 percent of whites but only 4.4 percent of blacks were in the richest income decile, meaning whites were 2.71 times more likely than blacks to belong to this select group), a decrease in income relative to the national mean also translated to a decrease relative to whites as a group. 

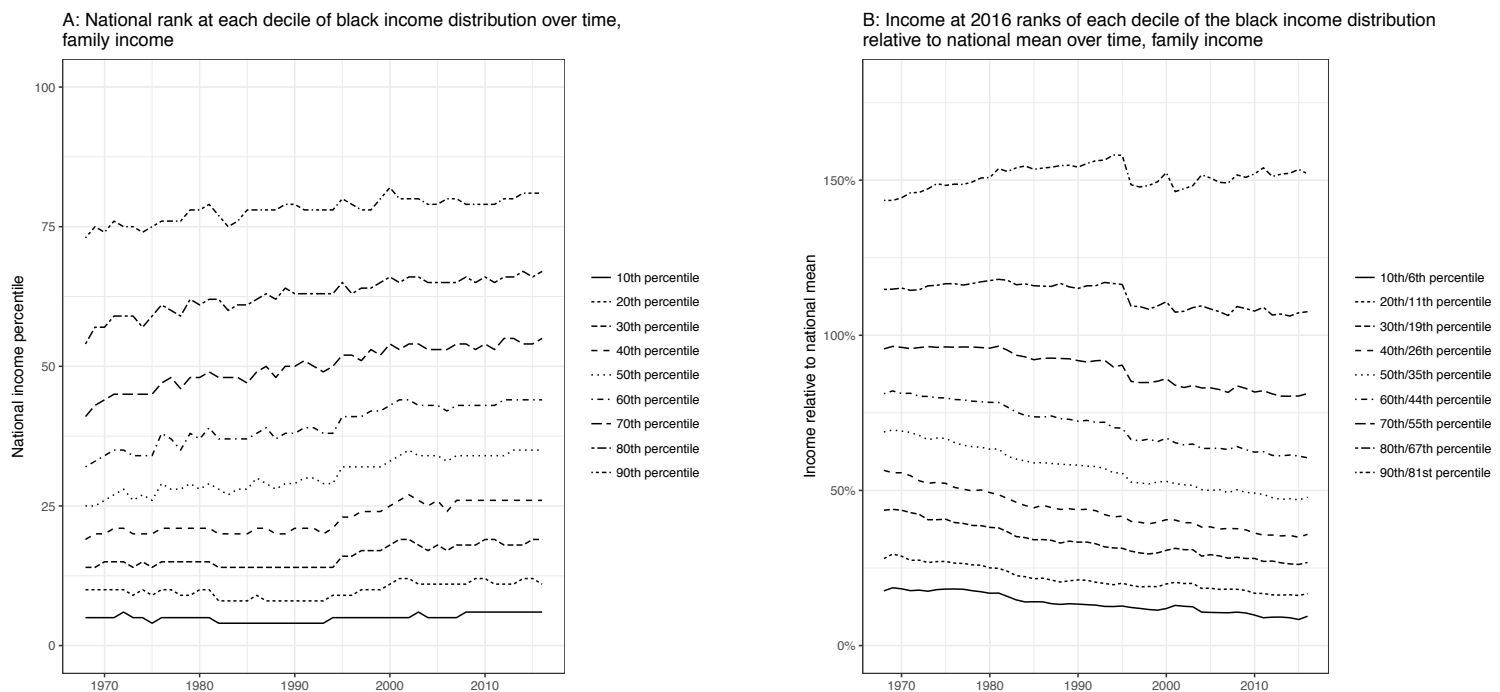

Figure 5: Trends in rank and incomes at each rank for each decile of the African American income distribution.

\section{Quantifying the Effect of the Changing Distribution}

What would have happened to racial disparities if income inequality hadn't gone up? To determine this, I construct a counterfactual scenario in which I hold the income of each percentile relative to the national mean constant at its 1968 value. I then allow African Americans to progress up the income distribution as they did in reality and re-compute the black-white median income ratio for this hypothetical scenario. The results are shown in Figure 6A. If the income distribution had remained stable, the black-white median family income ratio would have risen from 57 percent to 70 percent, closing 30 percent of the gap. Black-white income disparities would still be present in a world without rising income inequality, but they would have narrowed meaningfully over the past 50 years.

Figure 6B explores the opposite scenario: what if the income distribution had changed, but blacks had not made the relative progress described above? Here, I plot the ratio of the 25th percentile of family income to the 54th percentilethe median black and white ranks in 1968, respectively-over time. If African Americans had not made relative progress, changes to the income distribution alone would have decreased the ratio of median black to white family income from 57 percent in 1968 to 44 percent in 2016. It is only because of relative progress that the racial income gap did not get much worse.

In sum, the remarkably steady black-white family income ratio of the past 50 years is the product of two opposing trends. Blacks made substantial though incomplete progress in rank terms, with the median African American moving from the 25th percentile of family income to the 35th percentile. But these gains were counteracted by the national trend of rising income inequality, which resulted in a much larger share of the national economic pie going to the richest few percent of 

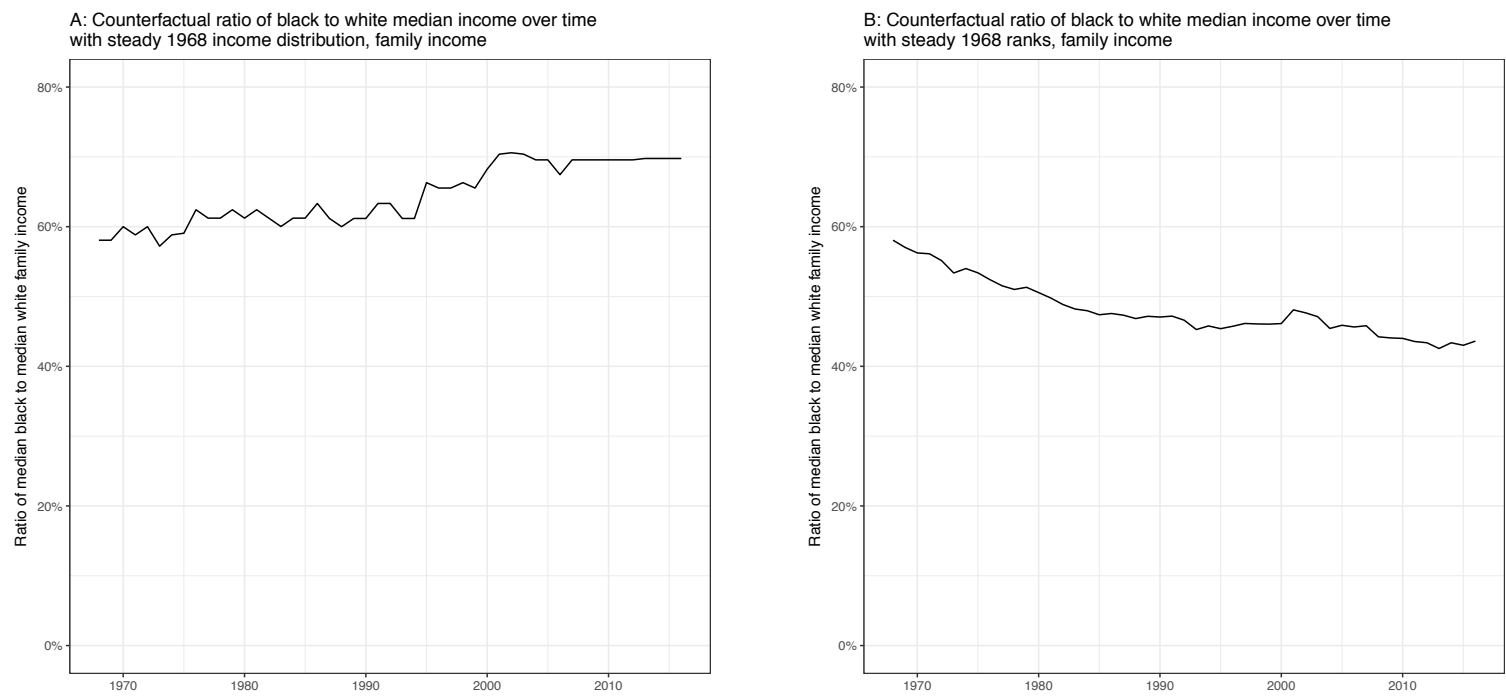

Figure 6: Counterfactual simulations.

the country, who remain disproportionately white. If the income distribution had remained constant, almost one-third of the racial income gap would have closed during this period. Without the progress in rank terms, the gap would have risen by 30 percent.

\section{Discussion}

Large racial gaps in living standards have persisted in the decades since the civil rights movement. In 1968, the median family income among African Americans was 57 percent as large as that among whites. In 2016, the ratio was 56 percent. This racial gap in living standards has hardly budged despite real if incomplete progress in reducing racial gaps in college attendance and high school achievement (Jencks and Phillips 2011; Ryan and Bauman 2016).

In this article, I have shown that the near-perfect stability in overall black-white income ratios is the result of two large but diametrically opposed trends. On the one hand, African Americans have made meaningful progress up the income distribution. The median African American had a family income at the 25th percentile of the national distribution in 1968 and had climbed to the 35th percentile in 2016. A similar upward trajectory in rank terms occurred throughout the African American income distribution. This improvement is limited, certainly, but it is not nothing.

However, these relative gains were offset by changes to the income distribution that allocated a much smaller share of the national income to the poor and middle class, in which African Americans were and continue to be disproportionately concentrated, and a much larger share to the top 10 percent and especially the top 1 percent-the portions of the distribution that remain the most disproportionately 
white. As the very rich absorbed larger and larger shares of the economy, the middle class slid back, reducing the payoff in dollars that was associated with progress in rank. These two forces almost perfectly balanced each other, resulting in hardly any net change in black-white income ratios.

It is important to note that the mechanism I have described based on rising inequality at the national level operates distinctly from racial differences in family structure, which also contribute to racial disparities in family income. Previous research has documented that differences in family structure between whites and blacks are a major reason for the continued presence of racial disparities in family income (Bloome 2014; Isaacs 2007). But this trend cannot explain the phenomenon described here. Racial differences in family structure contribute to the rank gap between blacks and whites because they result in African Americans clustering in family structures, such as single-parent families, with systematically lower incomes than the family structures that are more common among whites. Despite these differences in family structure, I have shown that there was a net decrease in the black-white rank gap in family income from 1968 to 2016. Because of rising inequality, however, that progress in rank terms did not translate into similar progress in dollars.

These findings for family incomes based on the Current Population Survey largely corroborate recent work using Decennial Census data to show the importance of structural changes to the economy for black-white earnings disparities among working-age men (Bayer and Charles 2016). In contrast to the trends for working-age men, for whom the median gap in ranks remained roughly stable during my sample period while the gap in dollars increased, my analysis of family income shows a narrowing of the rank gap combined with stability in the dollar gap. This difference may indicate that trends in racial income disparities among women are more positive than those among men. My results also align with previous research suggesting that overall rises in inequality have played a large role in maintaining black-white wage gaps (Couch and Daly 2002; Juhn et al. 1991; Wilson and Rodgers 2016) and that wage rank stratification between blacks and whites has declined since 1980 (Zhou 2012).

My results present reasons for both optimism and pessimism. On the one hand, they document small but real progress toward racial economic equality. This progress, insufficient as it is, has been underappreciated by commentators on all sides who have observed the stubborn persistence of racial income disparities. There was meaningful, if limited, convergence in the economic experiences of blacks and whites over the past 50 years. This suggests that some combination of equal-opportunity legislation, school desegregation, cultural changes, and sheer persistence on the part of African Americans resulted in real progress up the income distribution (albeit not yet to parity with whites).

On the other hand, this relative economic progress has meant little in terms of actual dollars. Because middle-class incomes have stagnated while upper-class and especially elite incomes continue to skyrocket, the movement of unprecedented numbers of blacks into the middle class occurred just as the fortunes of that group were fading. The result was that the black-white income gap stayed constant when 
it would have fallen by almost one-third if the income distribution had remained stable.

In addition to essentially negating the last five decades of slow racial progress, the skewed income distribution will reduce the benefits of any future relative gains. Any increase in the relative economic rank of blacks compared to whites will translate into a smaller increase in their relative incomes except to the extent that they are able to penetrate the most elite strata of U.S. society. The uphill climb toward racial parity is now steeper than it was when the Civil Rights Act was passed.

For sociologists, these results lend renewed urgency to previous calls to give greater attention to the effects of structural changes in the economy on racial economic outcomes (Leicht 2008; Morris and Western 1999; Wilson 2009). Much sociological research on racial inequality has focused, with good reason, on the extent and consequences of prejudice and discrimination (see the reviews in Pager and Shepherd 2008; Quillian 2006; Reskin 2012). Often, these studies have focused on the allocation processes that create and reproduce racial stratification. Here, I have documented a situation in which racial groups are becoming less stratifiedthere is more overlap in the family income distributions of blacks and whites today than there was in 1968 - and yet macroeconomic changes to the income distribution have negated these gains.

Beyond studies of racial inequality, work in sociology has been critiqued for focusing on individual actions at the expense of broader social structures in ways that lead to incomplete understanding of social phenomena (Mayhew 1980; Watts 2014). The theoretical mechanism explored here-that once groups are stratified, their relative positions can be altered by facially neutral processes, as suggested by Blau's macrosociological theory of social structure (1974, 1977a, 1977b) - is relevant in many social contexts. For example, such a process is a primary reason why the U.S. gender pay gap remains larger than those in other developed countries (Blau and Kahn 1996; Mandel and Semyonov 2005).

For citizens and policymakers, my results emphasize the importance of the second front in the battle for racial equality that many political leaders (A. Philip Randolph Institute 1966; Jackson 1984; King 1968) and academics (Darity and Hamilton 2012; Henderson 1976; Wilson 1999) have advocated over the years. To be sure, efforts to reduce discrimination and ensure that blacks and whites are equally prepared for the labor market should continue at full speed. They appear to have had some effect but can be nowhere near complete because blacks at every level of the skill and occupational hierarchy have economic outcomes similar to whites who are one or several notches below them (Grodsky and Pager 2001; Hamilton et al. 2015; Oliver and Shapiro 1995). But such efforts should be paired with universal efforts to unskew the income distribution and reverse the "winner-take-all" nature of the current U.S. economy (Hacker and Pierson 2010). A reorientation of the economy back to the needs of ordinary Americans will help the poor and middle class of all races while reducing economic disparities between blacks and whites. ${ }^{4}$

In addition to reducing current racial disparities, unskewing the income distribution will multiply the effect of any further relative racial progress because the monetary returns to each incremental increase in rank will rise dramatically. It 
should also lay the groundwork for a further narrowing of the rank gap: parental and community economic resources are major drivers of child success (Duncan and Brooks-Gunn 1999; Sharkey 2013), and interactions across racial groups as relative equals are one of the best-known ways to reduce prejudice (Allport 1979; Pettigrew and Tropp 2006).

Equally important, an agenda of reversing income stagnation and ending the winner-take-all economy presents ample opportunity for political coalitions (Wilson 1999). Many people of all races have been harmed by the economic shifts of the last 40 years. These changes have created a generation of children who are no better off on average than their parents were (Chetty et al. 2017), undermined the institution of marriage (Autor, Dorn, and Hanson 2017; Wilson 1996), and likely contributed to an epidemic of "deaths of despair" among those left behind (Case and Deaton $2015,2017)$. In this article, I have shown that progress toward racial equality also numbers among the casualties.

\section{Notes}

1 Data on Hispanic ethnicity is unavailable prior to 1971 . For the years 1968 to 1970 I therefore include Hispanics who identify as black or white in those respective groups.

2 The CPS did not ask about nativity until 1994, so this analysis uses the baseline sample prior to that year.

3 Because the CPS does not sample institutionalized populations, I use the Decennial Census and American Community Survey (ACS), which I also downloaded from the IPUMS project (Ruggles et al. 2015). I compute the overall institutionalization rate by race for each Census or ACS year and linearly interpolate between samples. I define as institutionalized those respondents who were in correctional facilities, mental institutions, or homes for the elderly. I then assume that the entire institutionalized population earns less than the median of their particular racial group and compute the overall statistics accordingly.

4 This is true unless such a reorientation is done in a white supremacist way. Successful reorientations of the economy toward the middle class in the past were deliberately targeted to avoid helping African Americans even as they lifted up the rest of the country (Katznelson 2005).

\section{References}

A. Philip Randolph Institute. 1966. A "Freedom Budget" for All Americans: Budgeting Our Resources 1966-1975, to Achieve Freedom from Want. New York, NY: A. Philip Randolph Institute.

Abel, Jaison R., Richard Deitz, and Yaqin Su. 2014. “Are Recent College Graduates Finding Good Jobs?" Current Issues in Economics and Finance 20(1):1-8.

Alderson, Arthur S., and Francois Nielsen. 2002. "Globalization and the great U-turn: Income inequality trends in 16 OECD countries." American Journal of Sociology 107(5):1244-99. https://doi.org/10.1086/341329.

Allport, Gordon Willard. 1979. The Nature of Prejudice. New York, NY: Basic Books. 
Autor, David H. 2014. "Skills, Education, and the Rise of Earnings Inequality among the 'Other 99 Percent"' Science 344(6186):843-51. https://doi .org/10.1126/science. 1251868.

Autor, David H., David Dorn, and Gordon Hanson. 2016. “The China Shock: Learning from Labor Market Adjustment to Large Changes in Trade." Annual Review of Economics 8(1):205-40. https://doi .org/10.1146/annurev-economics-080315-015041.

Autor, David H., David Dorn, and Gordon Hanson. 2017. “When Work Disappears: Manufacturing Decline and the Falling Marriage-Market Value of Men." NBER Working Paper No. 23713, Cambridge, MA.

Autor, David H., Frank Levy, and Richard J. Murnane. 2003. “The Skill Content of Recent Technological Change: An Empirical Exploration." Quarterly Journal of Economics 118(4):1279-333. https://doi.org/10.1162/003355303322552801.

Bayer, Patrick, and Kerwin Kofi Charles. 2016. "Divergent Paths: Structural Change, Economic Rank, and the Evolution of Black-White Earnings Differences 1940-2014." NBER Working Paper No. 22797, Cambridge, MA.

Bendick, Marc, Charles W. Jackson, and Victor A. Reinoso. 1994. "Measuring Employment Discrimination through Controlled Experiments." The Review of Black Political Economy 23(1):25-48. https://doi.org/10.1007/BF02895739.

Bertrand, Marianne, and Sendhil Mullainathan. 2004. "Are Emily and Greg More Employable than Lakisha and Jamal? A Field Experiment on Labor Market Discrimination." The American Economic Review 94(4):991-1013. https ://doi .org/10.1257/0002828042002561.

Blank, Rebecca M. 2001. "An Overview of Trends in Social and Economic Well-Being, by Race." Pp. 21-39 in America Becoming: Racial Trends and Their Consequences. Vol. 1, edited by N. J. Smelser, W. J. Wilson, and F. Mitchell. Washington, DC: National Academies Press.

Blau, Francine D., and Lawrence M. Kahn. 1996. “Wage Structure and Gender Earnings Differentials: An International Comparison." Economica 60(250): S29-62. https://doi . org/10.2307/2554808.

Blau, Peter M. 1974. "Presidential Address: Parameters of Social Structure." American Sociological Review 39(5):615-35. https ://doi .org/10.2307/2094309.

Blau, Peter M. 1977a. "A Macrosociological Theory of Social Structure." American Journal of Sociology 83(1):26-54. https : //doi .org/10.1086/226505.

Blau, Peter M. 1977b. Inequality and Heterogeneity: A Primitive Theory of Social Structure. New York, NY: Free Press.

Blinder, Alan S. 1973. "Wage Discrimination: Reduced Form and Structural Estimates." Journal of Human Resources 8(4):436-55. https : //doi .org/10.2307/144855.

Bloome, Deirdre. 2014. "Racial Inequality Trends and the Intergenerational Persistence of Income and Family Structure." American Sociological Review 79(6):1196-225. https: //doi.org/10.1177/0003122414554947.

Bobo, Lawrence D., Camille Z. Charles, Maria Krysan, Alicia D. Simmons, and George M. Fredrickson. 2012. "The Real Record on Racial Attitudes." Pp. 38-83 in Social Trends in American Life: Findings from the General Social Survey Since 1972, edited by P. V. Marsden. Princeton, NJ: Princeton University Press. https://doi.org/10.1515/ 9781400845569-005.

Bollinger, Christopher R., Barry T. Hirsch, Charles M. Hokayem, and James P. Ziliak. 2014. "Trouble in the Tails: Earnings Non-Response and Response Bias across the Distribution." 
Paper presented at the Annual Meeting of the Society of Labor Economists, May 2-3, Arlington, VA.

Bound, John, and Richard B. Freeman. 1992. "What Went Wrong? The Erosion of Relative Earnings and Employment among Young Black Men in the 1980s." Quarterly Journal of Economics 107(1):201-32. https://doi .org/10.2307/2118327.

Bradbury, Katharine L. 2002. "Education and Wages in the 1980s and 1990s: Are All Groups Moving up Together?" New England Economic Review, First Quarter, 19-46.

Cancio, A. Silvia, T. David Evans, and David J. Maume, Jr. 1996. "Reconsidering the Declining Significance of Race: Racial Differences in Early Career Wages." American Sociological Review 61(4):541-56. https://doi .org/10.2307/2096391.

Case, Anne, and Angus Deaton. 2015. "Rising Morbidity and Mortality in Midlife among White Non-Hispanic Americans in the 21st Century." Proceedings of the National Academy of Sciences 112(49):15078-83. https://doi .org/10.1073/pnas .1518393112.

Case, Anne, and Angus Deaton. 2017. "Mortality and Morbidity in the 21st Century." Brookings Papers on Economic Activity, 23-4. https: //doi.org/10.1353/eca.2017.0005.

Chetty, Raj, David Grusky, Maximilian Hell, Nathaniel Hendren, Robert Manduca, and Jimmy Narang. 2017. “The Fading American Dream: Trends in Absolute Income Mobility Since 1940." Science 356(6336):398-406. https : //doi . org/10.1126/science . aal4617.

Comanor, William S., and Robert H. Smiley. 1975. "Monopoly and the Distribution of Wealth." Quarterly Journal of Economics 89(2):177-94. https://doi .org/10.2307/1884423.

Couch, Kenneth, and Mary C. Daly. 2002. "Black-White Wage Inequality in the 1990s: A Decade of Progress." Economic Inquiry 40(1):31-41. https : //doi .org/10.1093/ei/40.1. 31.

Darity, William. 1998. "Intergroup Disparity: Economic Theory and Social Science Evidence." Southern Economic Journal 64(4):806-26. https : //doi .org/10.2307/1061206.

Darity, William, and Darrick Hamilton. 2012. "Bold Policies for Economic Justice." The Review of Black Political Economy 39(1):79-85. https : //doi .org/10.1007/s12114-011-9129-8.

Darling-Hammond, Linda. 1998. “Unequal Opportunity: Race and Education.” The Brookings Review 16(2):28-32. https: //doi.org/10.2307/20080779.

DiNardo, John, Nicole M. Fortin, and Thomas Lemieux. 1996. “Labor Market Institutions and the Distribution of Wages, 1973-1992: A Semiparametric Approach." Econometrica 64(5):1001-44 https://doi.org/10.2307/2171954.

Dobbin, Frank, and John R. Sutton. 1998. “The Strength of a Weak State: The Rights Revolution and the Rise of Human Resources Management Divisions." American Journal of Sociology 104(2):441-76. https: //doi .org/10.1086/210044.

Duncan, Greg J., and Jeanne Brooks-Gunn. 1999. Consequences of Growing Up Poor. New York, NY: Russell Sage Foundation.

Farley, Reynolds. 1998. The New American Reality: Who We Are, How We Got Here, Where We Are Going. New York, NY: Russell Sage Foundation.

Flood, Sarah, Miriam King, Steven Ruggles, and J. Robert Warren. 2015. Integrated Public Use Microdata Series, Current Population Survey Version 4.0. Minneapolis, MN: University of Minnesota.

Freeman, Richard B., and William M. Rodgers, III. 1999. “Area Economic Conditions and the Labor Market Outcomes of Young Men in the 1990s Expansion." NBER Working Paper No. 7073, Cambridge, MA. 
Gaddis, S. Michael. 2015. "Discrimination in the Credential Society: An Audit Study of Race and College Selectivity in the Labor Market." Social Forces 93(4):1451-79. https : //doi.org/10.1093/sf/sou111.

Goldin, Claudia, and Lawrence F. Katz. 2010. The Race Between Education and Technology. Cambridge, MA: Harvard University Press.

Gottschalk, Peter. 1997. "Inequality, Income Growth, and Mobility: The Basic Facts." The Journal of Economic Perspectives 11(20):21-40. https://doi .org/10.1257/jep.11.2.21.

Grodsky, Eric, and Devah Pager. 2001. "The Structure of Disadvantage: Individual and Occupational Determinants of the Black-White Wage Gap." American Sociological Review 66(4):542. https://doi.org/10.2307/3088922.

Hacker, Jacob S., and Paul Pierson. 2010. Winner-Take-All Politics. New York, NY: Simon and Schuster.

Hamilton, Darrick, Algernon Austin, and William Darity. 2011. “Whiter Jobs, Higher Wages: Occupational Segregation and the Lower Wages of Black Men." Economic Policy Institute Briefing Paper \#288, Washington, DC.

Hamilton, Darrick, William Darity, Anne E. Price, Vishnu Sridharan, and Rebecca Tippett. 2015. Umbrellas Don't Make It Rain: Why Studying and Working Hard Isn't Enough for Black Americans. Oakland, CA: Insight Center for Community Economic Development.

Harding, David J., Christopher Jencks, Leonard M. Lopoo, and Susan E. Mayer. 2005. “The Changing Effect of Family Background on the Incomes of American Adults." Pp. 100-44 in Unequal Chances: Family Background and Economic Success, edited by S. Bowles, H. Gintis, and M. O. Groves. Princeton, NJ: Princeton University Press.

Harrison, Bennett, Chris Tilly, and Barry Bluestone. 1986. "Wage Inequality Takes a Great U-Turn." Challenge 29(1):26-32. https ://doi .org/10.1080/05775132 .1986.11471066.

Hecker, Daniel E. 1992. "Reconciling Conflicting Data on Jobs for College Graduates." Monthly Labor Review 115(3):3-12.

Henderson, Vivian W. 1976. "Race, Economics, And Public Policy." Equity and Excellence in Education 14(1):13-17. https://doi.org/10.1080/0020486760140105.

Huffman, Matt L. 2004. "More Pay, More Inequality? The Influence of Average Wage Levels and the Racial Composition of Jobs on the Black-White Wage Gap." Social Science Research 33(3):498-520. https://doi.org/10.1016/j.ssresearch.2003.06.004.

Isaacs, Julia. 2007. Economic Mobility of Black and White Families. Washington, DC: Brookings Institution.

Jackson, Jesse. 1984. "1988 Democratic National Convention Address." Speech at the Democratic National Convention, July 18, San Francisco, CA. Retrieved July 13, 2017. http:/ /boyscoutflags.org/uploads/3/4/4/6/34469904/1984_democratic_national_convention_address_jessie_jackson.pdf.

Jacobs, David, and Jonathan C. Dirlam. 2016. "Politics and Economic Stratification: Power Resources and Income Inequality in the United States." American Journal of Sociology 122(2):469-500. https://doi.org/10.1086/687744.

James, Erika Hayes, and Lynn Perry Wooten. 2006. “Diversity Crises: How Firms Manage Discrimination Lawsuits." Academy of Management Journal 49(6):1103-18. https://doi . org/10.5465/AMJ . 2006.23478091.

Jencks, Christopher, and Meredith Phillips. 2011. The Black-White Test Score Gap. Washington, DC: Brookings Institution Press. 
Johnson, David S., Timothy M. Smeeding, and Barbara Boyle Torrey. 2005. "Economic Inequality through the Prisms of Income and Consumption." Monthly Labor Review 128(4):11-24.

Juhn, Chinhui, Kevin M. Murphy, and Brooks Pierce. 1991. "Accounting for the Slowdown in Black-White Wage Convergence." Pp. 107-43 in Workers and Their Wages, edited by M. H. Kosters. Washington DC: AEI Press.

Katznelson, Ira. 2005. When Affirmative Action Was White: An Untold History of Racial Inequality in Twentieth-Century America. New York, NY: W. W. Norton \& Company.

Khan, Lina, and Sandeep Vaheesan. 2016. "Market Power and Inequality: The Antitrust Counterrevolution and Its Discontents." SSRN Scholarly Paper ID 2769132, Rochester, NY.

Kim, ChangHwan, and Arthur Sakamoto. 2008. "The Rise of Intra-Occupational Wage Inequality in the United States, 1983 to 2002." American Sociological Review 73(1):129-57. https://doi.org/10.1177/000312240807300107.

King, Martin Luther, Jr. 1968. Where Do We Go from Here: Chaos or Community? Boston, MA: Beacon Press.

King, Mary C. 1992. “Occupational Segregation by Race and Sex 1940-88." Monthly Labor Review 115(4):30-7.

Kochanek, Kenneth D., Elizabeth Arias, and Robert N. Anderson. 2013. How Did Cause of Death Contribute to Racial Differences in Life Expectancy in the United States in 2010? (NCHS Data Brief, No. 125). Hyattsville, MD: National Center for Health Statistics.

Kozol, Jonathan. 1991. Savage Inequalities: Children in America's Schools. New York, NY: Harper Perennial.

Lee, David S. 1999. “Wage Inequality in the United States during the 1980s: Rising Dispersion or Falling Minimum Wage?" Quarterly Journal of Economics 114(3):977-1023. https: //doi.org/10.1162/003355399556197.

Leicht, Kevin T. 2008. "Broken Down by Race and Gender? Sociological Explanations of New Sources of Earnings Inequality." Annual Review of Sociology 34(1):237-55. https : //doi.org/10.1146/annurev.soc.34.040507.134627.

Lemieux, Thomas. 2006. "Increasing Residual Wage Inequality: Composition Effects, Noisy Data, or Rising Demand for Skill?" The American Economic Review 96(3):461-98. https : //doi.org/10.1257/aer.96.3.461.

Levy, Frank, and Richard J. Murnane. 1992. “US Earnings Levels and Earnings Inequality: A Review of Recent Trends and Proposed Explanations." Journal of Economic Literature 30(3):1333-81.

Levy, Frank, and Peter Temin. 2007. "Inequality and Institutions in 20th Century America.” NBER Working Paper No. 13106, Cambridge, MA.

Mandel, Hadas, and Moshe Semyonov. 2005. "Family Policies, Wage Structures, and Gender Gaps: Sources of Earnings Inequality in 20 Countries." American Sociological Review 70(6):949-67. https://doi.org/10.1177/000312240507000604.

Martin, Molly A. 2006. "Family structure and income inequality in families with children, 1976 to 2000." Demography 43(3):421-45. https : //doi .org/10.1353/dem. 2006. 0025.

Mayhew, Bruce H. 1980. "Structuralism versus Individualism: Part 1, Shadowboxing in the Dark." Social Forces 59(2):335-75. https://doi.org/10.1093/sf/59.2.335.

Morris, Martina, and Bruce Western. 1999. "Inequality in Earnings at the Close of the Twentieth Century." Annual Review of Sociology 25(1):623-57. https://doi.org/10. 1146/annurev.soc.25.1.623. 
Moss, Philip, and Chris Tilly. 1996. "'Soft' Skills and Race: An Investigation of Black Men's Employment Problems." Work and Occupations 23(3):252-76. https : //doi .org/10.1177/ 0730888496023003002.

Nam, Yunju, Darrick Hamilton, William Darity, and Anne E. Price. 2015. Bootstraps Are for Black Kids: Race, Wealth, and the Impact of Intergenerational Transfers on Adult Outcomes. Oakland, CA: Insight Center for Community Economic Development.

Neal, Derek A. 2006. “Why Has Black-White Skill Convergence Stopped?” Pp. 511-76 in Handbook of the Economics of Education. Vol. 1, edited by E. Hanushek and F. Welch. Amsterdam, Netherlands: North-Holland. https ://doi .org/10.1016/S1574-0692 (06) 01009-9.

Neal, Derek A., and William R. Johnson. 1996. "The Role of Premarket Factors in BlackWhite Wage Differences." Journal of Political Economy 104(5):869-95. https : //doi .org/ $10.1086 / 262045$.

Oaxaca, Ronald. 1973. "Male-Female Wage Differentials in Urban Labor Markets." International Economic Review 14(3):693-709. https://doi .org/10.2307/2525981.

Oliver, Melvin L., and Thomas M. Shapiro. 1995. Black Wealth, White Wealth: A New Perspective on Racial Inequality. New York, NY: Routledge.

Orfield, Gary, and Chungmei Lee. 2005. Why Segregation Matters: Poverty and Educational Inequality. Cambridge, MA: The Civil Rights Project, Harvard University.

Pager, Devah. 2003. "The Mark of a Criminal Record." American Journal of Sociology 108(5):93775. https://doi.org/10.1086/374403.

Pager, Devah, Bart Bonikowski, and Bruce Western. 2009. “Discrimination in a Low-Wage Labor Market: A Field Experiment." American Sociological Review 74(5):777-99. https : //doi.org/10.1177/000312240907400505.

Pager, Devah, and Hana Shepherd. 2008. "The Sociology of Discrimination: Racial Discrimination in Employment, Housing, Credit, and Consumer Markets." Annual Review of Sociology 34(1):181-209. https : //doi . org/10.1146/annurev . soc . 33.040406 . 131740.

Pedriana, Nicholas, and Robin Stryker. 2017. “From Legal Doctrine to Social Transformation? Comparing US Voting Rights, Equal Employment Opportunity, and Fair Housing Legislation." American Journal of Sociology 123(1):86-135. https : //doi .org/10 . 1086/692094.

Pettigrew, Thomas F., and Linda R. Tropp. 2006. "A Meta-Analytic Test of Intergroup Contact Theory." Journal of Personality and Social Psychology 90(5):751. https : //doi .org/10.1037/ 0022-3514.90.5.751.

Piketty, Thomas, Emmanuel Saez, and Stefanie Stantcheva. 2014. “Optimal Taxation of Top Labor Incomes: A Tale of Three Elasticities." American Economic Journal: Economic Policy 6(1):230-71. https://doi .org/10.1257/pol.6.1.230.

Piketty, Thomas, Emmanuel Saez, and Gabriel Zucman. 2016. “Distributional National Accounts: Methods and Estimates for the United States." NBER Working Paper No. 22945, Cambridge, MA.

Quillian, Lincoln. 2006. “New Approaches to Understanding Racial Prejudice and Discrimination." Annual Review of Sociology 32(1):299-328. https : //doi .org/10.1146/annurev . soc. 32.061604.123132.

Reskin, Barbara. 2012. "The Race Discrimination System." Annual Review of Sociology 38(1):17-35. https://doi .org/10.1146/annurev-soc-071811-145508.

Ruggles, Steven, Katie Genadek, Ronald Goeken, Josiah Grover, and Matthew Sobek. 2015. Integrated Public Use Microdata Series: Version 6.0. Minneapolis, MN: University of Minnesota. 
Ryan, Camille L., and Kurt Bauman. 2016. Educational Attainment in the United States: 2015. Population Characteristics (Current Population Reports, No. P20-578). Washington, DC: US Census Bureau.

Sharkey, Patrick 2013. Stuck in Place: Urban Neighborhoods and the End of Progress toward Racial Equality. Chicago, IL: University of Chicago Press. https ://doi . org/10.7208/chicago/ 9780226924267.001 .0001$.

Smelser, Neil J., William J. Wilson, and Faith Mitchell. 2001. “Introduction.” Pp. 1-20 in America Becoming: Racial Trends and Their Consequences. Vol. 1., edited by N. J. Smelser, W. J. Wilson, and F. Mitchell. Washington, DC: National Academies Press.

Smith, James P. 1993. "Affirmative Action and the Racial Wage Gap." The American Economic Review 83(2):79-84.

Tomaskovic-Devey, Donald. 1993. “The Gender and Race Composition of Jobs and the Male/Female, White/Black Pay Gaps." Social Forces 72(1):45-76. https : //doi .org/10. $1093 / \mathrm{sf} / 72.1 .45$.

Volscho, Thomas W., and Nathan J. Kelly. 2012. "The Rise of the Super-Rich: Power Resources, Taxes, Financial Markets, and the Dynamics of the Top 1 Percent 1949 to 2008." American Sociological Review 77(5):679-99. https://doi .org/10.1177/0003122412458508.

Watts, Duncan J. 2014. "Common Sense and Sociological Explanations." American Journal of Sociology 120(2):313-51. https://doi .org/10.1086/678271.

Weeden, Kim A. 2002. "Why Do Some Occupations Pay More than Others? Social Closure and Earnings Inequality in the United States." American Journal of Sociology 108(1):55-101. https://doi.org/10.1086/344121.

Western, Bruce, and Becky Pettit. 2005. "Black-White Wage Inequality, Employment Rates, and Incarceration." American Journal of Sociology 111(2):553-78. https://doi .org/10. $1086 / 432780$.

Western, Bruce, Deirdre Bloome, and Christine Percheski. 2008. "Inequality among American families with children, 1975 to 2005." American Sociological Review 73(6):903-20. https : //doi.org/10.1177/000312240807300602.

Western, Bruce, and Jake Rosenfeld. 2011. "Unions, Norms, and the Rise in US Wage Inequality." American Sociological Review 76(4):513-37. https://doi.org/10.1177/ 0003122411414817.

Wilson, Valerie. 2015. The Impact of Full Employment on African American Employment and Wages. Washington, DC: Center on Budget and Policy Priorities.

Wilson, Valerie, and William M. Rodgers, III. 2016. Black-White Wage Gaps Expand with Rising Wage Inequality. Washington, DC: Economic Policy Institute.

Wilson, William J. 1978. The Declining Significance of Race: Blacks and Changing American Institutions. Chicago, IL: University of Chicago Press.

Wilson, William J. 1987. The Truly Disadvantaged: The Inner City, the Underclass, and Public Policy. Chicago, IL: University of Chicago Press.

Wilson, William J. 1996. When Work Disappears: The World of the New Urban Poor. New York, NY: Vintage.

Wilson, William J. 1999. The Bridge over the Racial Divide: Rising Inequality and Coalition Politics. Oakland, CA: University of California Press.

Wilson, William J. 2000. "Rising Inequality and the Case for Coalition Politics." The Annals of the American Academy of Political and Social Science 568(1):78-99. https : //doi . org/10 . $1177 / 000271620056800107$. 
Wilson, William J. 2009. More than Just Race: Being Black and Poor in the Inner City. New York, NY: W. W. Norton \& Company.

Zhou, Xiang. 2012. “A Nonparametric Index of Stratification." Sociological Methodology 42(1):365-89. https://doi.org/10.1177/0081175012452207.

Acknowledgements: I am grateful to Victoria Asbury, Alex Bell, Lawrence Bobo, Hope Harvey, Nathaniel Hendren, Roland Neil, Devah Pager, Robert Sampson, Roseanna Sommers, James Sidanius, Mo Torres, Adam Travis, Bruce Western, and the seminar participants at the Harvard University Contemporary Studies of Race and Ethnicity Workshop for their helpful comments and feedback. This research has been supported by the Harvard Multidisciplinary Program in Inequality and Social Policy.

Robert Manduca: Department of Sociology, Harvard University.

E-mail: rmanduca@g.harvard.edu. 